\title{
Alt Solunum Yolu Enfeksiyonu Tanısı Alan Olgularda Nazal Kanül ile Yüksek Akımlı Oksijen Tedavisinin Klinik Sonuçları
}

Eren GÜZELOĞLU ${ }^{1}$, Nagihan AKAY $^{1}$, Șirin GÜVEN ${ }^{1}$

\begin{abstract}
Öz
Nazal kanül ile yüksek akımlı oksijen tedavisinin alt solunum yolu enfeksiyonlarının tedavisinde etkinliğini ve güvenilirliğini araştırmak amacıyla, tedavi edilen olguların klinik sonuçları retrospektif olarak değerlendirildi. Sancaktepe Eğitim Araştırma Hastanesinde 01/06/2017 - 01/08/2018 tarihleri arasinda alt solunum yolu enfeksiyonu tanısı ile yatan 195 olgu mevcut olup, olgulardan 26'sına nazal kanül ile yüksek akımlı oksijenizasyon tedavisi uygulandı. Olguların, tedavinin $0,1,4,8,12,24$. saatlerindeki dakika solunum sayısı(DSS), nabız ve pulseoksimetre ile ölçülen oksijen saturasyonları (SpO2) değerlerine, hasta dosyalarından ve kayıtlardan geriye dönük olarak ulaşıldı. Çalışma \%26,9'u (n=7) kız, \%73,1'i $(n=19)$ erkek olmak üzere toplam 26 olgu ile yapılmıştır. Olguların yaşları 2 ile 96 ay arasında değişmekte olup, ortalaması $10,23 \pm 18,15$ ve medyanı 6 aydır. Olguların \%73,1'ine $(n=19)$ pnömoni, \%26,9'una $(\mathrm{n}=7)$ ise bronşiyolit tanısı konulmuştur. Olguların nazal kanül ile yüksek akımlı oksijenizasyon tedavisinde kalış süreleri 24 ile 240 saat arasında değişmekte olup, ortalaması $83,08 \pm 52,24$ ve medyanı 72 saattir. Olguların tedavi öncesi, tedavi sonras1 1.saat, 4.saat, 8.saat, 12.saat ve 24.saatteki solunum sayıları arasında istatistiksel olarak anlamlı farklılık saptand $1(\mathrm{p}<0,01)$. Olguların tedavi öncesi, tedavi sonrası 1.saat, 4.saat, 8.saat, 12.saat ve 24.saatteki kalp atım sayıları arasında istatistiksel olarak anlamlı farklılık saptandı $(\mathrm{p}<0,01)$. Olguların tedavi öncesi, tedavi sonrası 1.saat, 4.saat, 8.saat, 12.saat ve 24.saatteki oksijen saturasyon düzeyleri arasında istatistiksel olarak anlaml farklılık saptandı $(\mathrm{p}<0,01)$. Nazal kanül ile yüksek akımlı oksijenizasyon tedavisi, yaşamsal bulgularda kısa süre içerisinde düzelme sağlamakla beraber, tedaviye bağlı yan etkilerin nadir görülmesi nedeniyle; alt solunum yolu enfeksiyonu olan olgularda, bu tedavinin kullanımının etkin ve güvenilir olduğu düşünülmüştür.
\end{abstract}

Anahtar Kelimeler: Pnömoni, bronşiolit, yüksek akımlı nazal kanül oksijenizasyon tedavisi, solunum sayısı, kalp atım sayısı
Yayın Bilgisi

Gönderi Tarihi: 09.09.2018

Kabul Tarihi: 04.12.2018

Online Yayın Tarihi: 30.09.2019

DOI: $10.26453 /$ otjhs. 458346

Sorumlu Yazar

Eren GÜZELOĞLU

TC Sağlık Bakanlığı Sancaktepe Şehit Prof. Dr. İlhan Varank Eğitim Araștırma Hastanesi Çocuk Sağlığı ve

Hastalıkları Kliniği

Tel: 05326602370

e-Mail: dr.erenguzeloglu@gmail.com

\section{Clinical Outcomes of High Flow Nasal Cannula Oxygenation Therapy in Patients with}

\section{Lower Respiratory Tract İnfection}

$\underline{\text { Eren GÜZELOĞLU }}^{1}$, Nagihan AKAY ${ }^{1}$, Sirin GÜVEN ${ }^{1}$

\begin{abstract}
A retrospective clinical study was conducted to evaluate the safety and efficacy of clinical outcomes in patients treated with high-flow nasal cannula oxygenation within one year in ourclinic. In Sancaktepe Educational Research Hospital, therewere 195 cases with lower respiratory tract infection diagnosis between 01/06/2017 - 01/08/2018 and high flow nasal cannula oxygenation treatment was applied to 26 cases. Values of $0,1,4,8,12,24$ hours were obtained from patients' files and records retrospectively in cases of respiratory rate, heart rate, oxygensaturation $(\mathrm{SpO} 2)$. Thestudyconsisted of 26 cases $(26.9 \%)(\mathrm{n}=7)$ and $73.1 \%(\mathrm{n}=19)$ men. The ages of the cases ranged from 2 to 96 months with a mean of $10.23 \pm 18.15$ and a median of 6 months. Pneumonia was diagnosed in $73.1 \%(n=19)$ andbronchiolitis in $26.9 \%(\mathrm{n}=7)$ of the cases. High-flow nasal cannula oxygenation therapy residence times ranged from 24 to 240 hours with a mean of $83,08 \pm 52,24$ and a median of 72 hours. There was a statistically significant difference $(p<0.01)$ between the pre-treatment and post-treatment 1. hour, 4. hour, 8. hour, 12. hour and 24 hour respiratory rates of the cases. There was a statistically significant difference $(p<0.01)$ between the pre-treatment and post-treatment 1. hour, 4. hour, 8. hour, 12. hour and 24 hour heart rates of the cases. There was a statistically significant difference $(p<0.01)$ between the pre-treatment and post- treatment 1 . hour, 4 . hour, 8 . hour, 12. hour and 24 hour oxygen saturation levels of the cases. High-flow nasal cannula oxygenation therapy provides in a short time improvement in vital signs, but side effects due to treatment are rare; it was thought that the use of this treatment was effective and reliable in cases with lower respiratory tract infection.
\end{abstract}

Keywords: Pneumonia, bronchiolitis, high flow nasal cannula oxygenation therapy, respiratory rate, heart rate 
${ }^{1}$ TC Sağlık Bakanlığı Sancaktepe Şehit Prof. Dr. İlhan Varank Eğitim Araştırma Hastanesi Çocuk Sağlığı ve Hastalıkları Kliniği, İstanbul.

\section{GíRIS}

Akut bronşiyolit (AB) iki yaşından küçük çocuklarda sıklıkla viral etkenlerin neden olduğu, hışıltı “wheezing”, öksürük, hızlı solunum, göğ̈̈ste çekilmeler ve ekspiryumda uzama ile karakterize bronşiyollerin inflamasyonu ile seyreden bir hastalıktır. İki yaş altındaki çocukların \%10-20'sinde görülebilir. Pnömoni sıklıkla bakteriler ve viruslar gibi infeksiyöz ya da infeksiyöz olmayan etkenlere yanıt olarak akciğer parankiminde (alveol ve interstisyum) gelişen akut bir inflamasyondur. ${ }^{1}$ Pnömoni; ateş, solunumsal belirtiler ve parankimal tutulumun fizik muayene ve/veya göğüs radyografi bulguları ile tanımlandığı klinik bir tablodur. Pnömonide antibiyotik tedavisi öncelikli tedavi olmakla beraber destek tedavilerine ihtiyaç duyulmaktadır. $^{2}$ Bronşiolit ve pnömoni tanılı ileri solunum yetmezliği olan olgularda noninvazif ventilasyon, mekanik ventilasyon uygulamaları gerekebilmektedir. Son dönemde yüksek akımlı nazal kanül oksijenizasyon tedavisi de kullanılmaya başlanmıştır. ${ }^{1,2}$ Nazal kanül ile yüksek akımlı oksijenizasyon tedavisinin, alt solunum yolu enfeksiyonu tanısı alan olgularda hastanede yatış süresini, mortalite ve morbiditeyi azalttığına yönelik klinik çalışmalar mevcuttur. Nazal kanül ile yüksek akımlı oksijenizasyon tedavisi, bir noninvazif ventilasyon yöntemi olup; yüksek akım tanımlaması $\geq 2 \mathrm{~L} / \mathrm{dk}$ akım hızında verilen oksijen tedavileri için kullanılmaktadır. Kullanılan kanül boyutuna hastanın yaş ve vücut ağırlığına göre akım hızı 70 L/dk ya kadar arttırılabilir. ${ }^{3-7}$ Kliniğimizde son bir yılda takip ettiğimiz olgularımızdaki nazal kanül ile yüksek akımlı oksijenizasyon tedavisi; klinik sonuçlarının etkinlik ve güvenirliğini değerlendirmek amacıyla, retrospektif klinik bir çalışma yapıldı.

\section{MATERYAL VE METOT}

Sancaktepe Eğitim Araştırma Hastanesinde 01/06/2017-01/08/2018 tarihleri arasinda alt solunum yolu enfeksiyonu tanısı ile yatan 195 olgu mevcut olup, olgulardan 26'sina nazal kanül ile yüksek akımlı oksijenizasyon tedavisi uyguland1. Olguların ateş, dakika solunum sayısı(DSS), nabız, oksijen saturasyonları (SpO2) 0, 1, 4, 8,12, 24. saat değerleri, hasta dosyalarından ve kayıtlardan geriye dönük olarak ulaşıldı. Türkiye Cumhuriyeti Sağlık Bakanlığı Fatih Sultan Mehmet Eğitim Araştırma Hastanesi'nden Girişimsel Olmayan Klinik Araştırmalar Etik Kurul onayı alındı. Çalışmada elde edilen bulgular değerlendirilirken, istatistiksel analizler için IBM SPSS Statistics 22 (IBM SPSS, Türkiye) 
programı kullanıldı. Değişkenlerin normal dağılıma uygunluğu Shapiro Wilks testi ile değerlendirildi.

Çalışma

verileri

değerlendirilirken tanımlayıcı istatistiksel metotların (ortalama, standart sapma, frekans) yanı sıra niceliksel verilerin iki grup arası değerlendirmelerde Mann Whitney $U$ testi kullanıldı. Normal dağılım göstermeyen niceliksel verilerin iki grup aras1 değerlendirmelerinde ise Mann Whitney U testi kullanıldı. Tekrarlayan niceliksel ölçümlerin değerlendirilmesinde Friedman testi kullanıldı. Farklılığa neden olan ölçümün değerlendirilmesinde ise Wilcoxon İşaretli Sıralar testi kullanıldı. Niteliksel verilerin değerlendirilmesinde Fisher Tam Ki-Kare testi kullanıldı. Anlamlılık $\mathrm{p}<0,05$ düzeyinde değerlendirildi.

\section{BULGULAR}

Çalışma \%26,9'u (n=7) kı, \%73,1'i (n=19) erkek olmak üzere toplam 26 olgu ile yapılmıştır. Olguların yaşları 2 ile 96 ay arasında değişmekte olup, ortalaması $10,23 \pm 18,15$ ve medyanı 6 aydır. Olguların $\% 73,1$ 'ine $(n=19)$ pnömoni, \%26,9'una $(n=7)$ ise bronşiyolit tanısı konulmuştur. Olguların nazal kanül ile yüksek akımlı oksijenizasyon tedavisi kalış süreleri 24 ile 240 saat arasında değişmekte olup, ortalaması $83,08 \pm 52,24$ ve medyanı 72 saattir. Olgulara nazal kanül ile yüksek akımlı oksijenizasyon tedavisi, akım $21 \mathrm{t} / \mathrm{kg} / \mathrm{dk}$ 'dan olacak şekilde uygulanmıştır.
Olgularin \%23,1'inde $\quad(n=6) \quad$ Seftriakson, $\% 11,5$ 'inde $(\mathrm{n}=3) \quad$ Oseltamivir, \%7,7'sinde $(\mathrm{n}=2) \quad$ Vankomisin, $\% 38,5$ 'inde $\quad(\mathrm{n}=10)$ Klaritromisin, \%15,4'ünde $(n=4)$ Sefotaksim, \%69,2'sinde ( $\mathrm{n}=18)$ Sulbaktam- Ampisilin, \%11,5'inde $\quad(\mathrm{n}=3) \quad$ Ampisilin, \%3,8'inde $(n=1) \quad$ Piperasilin-tazobaktam ve $\% 3,8$ 'inde $(\mathrm{n}=1) \quad$ Meropenem antibiyotiklerinin kullanıldığı saptand1. Olguların vücut sıcaklıklarının 37,3 ile 38,9 derece arasında değişmekte olup, ortalamasının $37,93 \pm 0,48$ ve medyanının 38 derece olduğu saptandı (Tablo $1)$.

Olguların \%26,9'unda $(\mathrm{n}=7)$ ise komorbidite (Astım, Parapnömonik efüzyon,Down sendromu, Serebral Palsi, Konjenital Kalp Hastalığı vb.) görüldüğ̈̈ saptandı. Olguların \%4'ünde $\quad(n=4) \quad$ klinik düzelme sağlanamaması ve eşlik eden komorbidite olması nedeniyle, olgular çocuk yoğun bakım ünitesine sevk edildi. Bir olguya parapnömonik efüzyon nedeniyle torasentez işlemi uygulandı. Torasentez işlemi sonrasında, olguda pnömotoraks gelişti. Pnömotoraks nazal kanül ile yüksek akımlı oksijenizasyon tedavisinin komplikasyonu olarak düşünülmedi.

Olguların tedavi öncesi, tedavi sonrası 1.saat, 4.saat, 8.saat, 12.saat ve 24.saatteki solunum sayıları arasında istatistiksel olarak anlamlı farklılık saptand $(p<0,01)$. Olguların tedavi öncesi, tedavi sonras1 1.saat, 4.saat, 8.saat, 12.saat ve 24.saatteki kalp atım sayıları 
arasında istatistiksel olarak anlamlı farklılık saptandı $(\mathrm{p}<0,01)$. Olguların tedavi öncesi, tedavi sonrasi 1.saat, 4.saat, 8.saat, 12.saat ve 24.saatteki oksijen saturasyon düzeyleri arasında istatistiksel olarak anlamlı farklılı saptand 1 ( $\mathrm{p}<0,01$; Tablo 2).

Tanı gruplar arasında tedavi öncesi, tedavi sonras1 1.saat, 4.saat, 8.saat, 12.saat ve 24.saatteki solunum sayıları açısından istatistiksel olarak anlamlı bir farklılık saptanmadi ( $>00,05$; Tablo 3 ).

Pnömoni tanısı alanlarda; tedavi öncesi, tedavi sonras1 1.saat, 4.saat, 8.saat, 12.saat ve 24.saatteki solunum sayıları arasında istatistiksel olarak anlamlı farklılık saptandı $(\mathrm{p}<0,01)$.

Bronşiyolit tanısı alanlarda; tedavi öncesi, tedavi sonrasi 1.saat, 4.saat, 8.saat, 12.saat ve 24.saatteki solunum sayıları arasında istatistiksel olarak anlamlı farklılık saptand1 $(\mathrm{p}<0,01)$.

Tanı gruplar arasında tedavi öncesi, tedavi sonras1 1.saat, 4.saat, 8.saat, 12.saat ve 24.saatteki kalp atım sayıları açısından istatistiksel olarak anlamlı bir farklılık saptanmadi $(p>0,05)$.

Pnömoni tanısı alanlarda; tedavi öncesi, tedavi sonras1 1.saat, 4.saat, 8.saat, 12.saat ve 24.saatteki kalp atım sayıları arasında istatistiksel olarak anlamlı farklılık saptand1 $(\mathrm{p}<0,01)$.

Bronşiyolit tanısı alanlarda; tedavi öncesi, tedavi sonrasi 1.saat, 4.saat, 8.saat, 12.saat ve 24.saatteki kalp atım sayıları arasında istatistiksel olarak anlamlı farklılık saptandı $(\mathrm{p}<0,01)$.

Tanı gruplar arasında tedavi öncesi, tedavi sonras1 1.saat, 4.saat, 8.saat, 12.saat ve 24.saatteki oksijen saturasyon düzeyleri açısından istatistiksel olarak anlamlı bir farklılık saptanmadı $(\mathrm{p}>0,05)$.

Pnömoni tanısı alanlarda; tedavi öncesi, tedavi sonras1 1.saat, 4.saat, 8.saat, 12.saat ve 24.saatteki oksijen saturasyon düzeyleri arasında istatistiksel olarak anlamlı farklılık saptand $_{1}(\mathrm{p}<0,01)$.

Bronşiyolit tanısı alanlarda; tedavi öncesi, tedavi sonrasi 1.saat, 4.saat, 8.saat, 12.saat ve 24.saatteki oksijen saturasyon (\%) düzeyleri arasında istatistiksel olarak anlamlı farklılık saptand $1(\mathrm{p}<0,01)$.

Çalışmamızdaki tüm olguların nazal kanül ile yüksek akımlı oksijenizasyon tedavisinde, ilk 24 saat içerisindeki kalp tepe atımı (nabız/dk), solunum sayısı (DSS) anlamlı düşüş gösterirken, Oksijen saturasyonu (yukarıdaki paragrafta bu terim farklı yazılmıştır.) ( $\mathrm{SpO} 2)$ anlamlı oranda yükseliş göstermiştir (Şekil 1).

\section{TARTIȘMA VE SONUÇ}

Solunum sıkıntısı ile takip edilen pnömoni ve bronşiolitli olguların klinik izleminde; nabız, solunum say1s1, oksijen saturasyonu $(\mathrm{SpO} 2)$ gibi yaşamsal bulgular önemli bir yer tutmaktadır. $^{1-2}$ Konvansiyonel oksijen 
tedavileri ile bu bulgularda her zaman düzelme görülmemektedir. Özellikle alt solunum yolu hastalıklarında ventilasyonu ve oksijenizasyonu daha iyi sağlayabilmek için nazal kanül ile yüksek akımlı oksijenizasyon tedavisine ihtiyaç duyulmaktadır. Literatüre bakıldığında; nazal kanül ile yüksek akımlı oksijenizasyon tedavisinin solunum sikıntısı ve/veya yetmezliği olan olgularda mortalite ve morbiditeyi belirgin olarak azalttığ görülmektedir. ${ }^{3-8}$

Çalışmamızda nazal kanül ile yüksek akımlı oksijenizasyon tedavisi uygulanan tüm olgular; nabız, solunum sayısı, oksijen saturasyonu değerleri ile izlenmiştir. Tedavinin 1. saatinden itibaren tüm yaşamsal bulguların, tedavi öncesine göre anlamlı düzeyde değişiklik olduğu görülmektedir. 1, 4, 8, 12, 24. saatlerdeki bulgular bir önceki değerle veya tedavi öncesi ile değerlerle kıyaslandığında anlamlı değişiklik saptanmıştır. Pnömonili ve bronşiolitli olguların özellikle tedavinin 12. saatinde solunum sayıs1, nabiz ve saturasyon değerlerinin normale geldiği ve istatistiksel olarak da 12. saat ve 24. saat değerlerinin daha anlamlı olduğu görülmektedir.

Söğütlü ve arkadaşlarının yaptığı çalışmada da, çalışmamızla benzer olarak yaşamsal bulguların tedavinin 1. saatinden itibaren, tedavi öncesine göre anlamlı saptandığ 1 ve en yüksek ortalama $\mathrm{SPO} 2$ değerine 24 . saatte ulaştığ1 görülmektedir. Benzer şekilde olguların tedavi başlangıcından sonraki yaşamsal bulgularının ortalama değerlerinin de iki tanı grubu arasında anlamlı fark göstermediği saptamıştır. ${ }^{3}$

Ergül ve arkadaşlarının akut bronşiolitli olgular üzerinde yaptığı çalışmada, nazal kanül ile yüksek akımlı oksijenizasyon tedavisi uygulanan olguların maske ile oksijen uygulanan olgulara göre daha kısa süre oksijen tedavisi aldığını göstermişlerdir. 5

Heikkilä ve arkadaşlarının bronşiolitli infantlar üzerinde yaptığı çalışmada da, nazal kanül ile yüksek akımlı oksijenizasyon tedavisinin, endotrakeal entübasyon gereksinimini ve yoğun bakımda yatış süresini azalttığı gösterilmiştir. ${ }^{10}$

Konca ve arkadaşlarının yayınladığı olgu sunumunda, nazal kanül ile yüksek akımlı oksijenizasyon tedavisine bağlı Pnömotoraks geliştiği belirtilmiștir. 9 Kliniğimizde tedavi esnasında pnömotoraks gelişen tek olgu mevcut olup, bu olguda da torasentez işlemi sonrasında pnömotoraks geliştiği düşünülmektedir. Ayrıca iki olgumuz tedaviye yanıt alınamaması nedeniyle çocuk yoğun bakım ünitesine sevk edilmiştir. Bu durumun da nazal kanül ile yüksek akımlı oksijenizasyon tedavisinin etkin olmamasından ziyade, olguların eşlik eden komorbid hastalıkları sebebi ile olduğu düşünülmüştür. 
Nazal kanül ile yüksek akımlı oksijenizasyon tedavisi, alt solunum yolu enfeksiyonu olan çocuklarda yaşamsal bulgularda özellikle ilk 24 saat içerisinde anlamlı düzelme sağlamıştır. Non- invaziv bir yöntem olması ve tedaviye bağlı yan etkilerin nadir görülmesi nedeniyle; nazal kanül ile yüksek akımlı oksijenizasyon tedavisinin, çocuklarda etkin ve güvenilir olduğu düşünülmüştür.

\section{KAYNAKLAR}

1. Yalçın E, Karadağ B, Uzuner N, et al. Türk Toraks Derneği Akut Bronşiolit Tanı ve Tedavi Uzlaşı Raporu. Turk Thorac J. 2009;10(1):1-7.

2. Kocabaș E, Ersöz D, Karakoç F, Tanır G, Cengiz AB, Gür D, Uyan A, Güler N, Haliloğlu M, Alabaz D. Türk Toraks Derneği Çocuklarda toplumda Gelişen Pnömoni Tanı ve Tedavi Uzlaşı Raporu. Turk Thorac J. 2009;10(3):1-24.

3. Söğütlü $Y$, Biçer $S$, Kurt $G$, et al. Alt Solunum Yolu Hastalığı Olan Çocuklarda Yüksek Akımlı Nazal Kanül Oksijenasyon Tedavisinin Yaşamsal Bulgular Üzerindeki Sonuçları. J Pediatr Emerg Intensive Care Med. 2016;3:121-30

4. Franklin D, Schibler A, et al. Nasal HighflowTherapy in Infants and Children. Paediatr Respirol Crit Care Med. 2018,2:26.

5. Ergül AB, Çalışkan E. Using a high flow nasal cannula provides superior results to OxyMask delivery in moderate to severe brochiolitis: a randomized controlled study. Eur J Pediatr. 2018;177(8):1299-1307.

6. Weiler T, Kamerkar A, Hotz J, et al. The Relationship between High Flow Nasal Cannula Flow Rate and Effort of Breathing in Children. J Pediatr. 2017;189:66-71.

7. Mikalsen IB, Davis $P$, et al. High flow nasal cannula in children: literature review. Scand J Trauma Resusc Emerg Med. 2016;12;24:93.

8. Coletti KD, Bakdure DN, et al. High-Flow Nasal Cannula Utilization in Pediatric Critical Care. Respir Care. 2017;62(8):1023-1029.

9. Konca Ç, Apaydın H, et al. Yüksek Akımlı Nazal Kanül Oksijenasyon Tedavisine Bağlı Pnömotoraks Olgusu. J Pediatr Emerg Intensive Care Med. 2017;4:80-83

10. Heikkilä P, Sokuri $\mathrm{P}$, et al. Using highflow nasal cannulas for infants with bronchiolitis admitted to paediatric wards is safe and feasible.Acta Paediatr. 2018; 107(11):1971-1976. 
Tablo 1. Pnömoni ve bronşiyolit olgularına ilişkin demografik özellikler.

\begin{tabular}{|c|c|c|c|c|c|c|}
\hline \multicolumn{2}{|c|}{ Demografik Özellikler } & $\begin{array}{c}\text { Pnömoni } \\
(n=19)\end{array}$ & $\begin{array}{c}\text { Bronşiyolit } \\
\quad(n=7)\end{array}$ & $\begin{array}{c}\text { Toplam } \\
(\mathrm{n}=26)\end{array}$ & \multirow[t]{2}{*}{$\chi^{2}$} & \multirow[t]{2}{*}{$\mathbf{P}$} \\
\hline & & n (\%) & n (\%) & n (\%) & & \\
\hline \multirow{2}{*}{ Cinsiyet } & $\mathbf{K} \mathbf{z}$ & $4(\% 21,1)$ & $3(\% 42,9)$ & $7(\% 26,9)$ & \multirow{2}{*}{1,236} & \multirow{2}{*}{0,340} \\
\hline & Erkek & $15(\% 78,9)$ & $4(\% 57,1)$ & $19(\% 73,1)$ & & \\
\hline \multirow{2}{*}{ Yaş } & $0-6$ ay & $10(\% 52,6)$ & $5(\% 71,4)$ & $15(\% 57,7)$ & \multirow{2}{*}{0,740} & \multirow{2}{*}{0,658} \\
\hline & $>6$ ay & $9(\% 47,4)$ & $2(\% 28,6)$ & $11(\% 42,3)$ & & \\
\hline \multirow{2}{*}{$\begin{array}{l}\text { Nazal kanül } \\
\text { tedavisinde } \\
\text { kalış süresi }\end{array}$} & $<72$ saat & $7(\% 36,8)$ & $2(\% 28,6)$ & $9(\% 34,6)$ & \multirow[b]{2}{*}{0,155} & \multirow[b]{2}{*}{1,000} \\
\hline & $\geq 72$ saat & $12(\% 63,2)$ & $5(\% 71,4)$ & $17(\% 65,4)$ & & \\
\hline \multirow{10}{*}{$\begin{array}{l}\text { Kullanılan } \\
\text { antibiyotikler }\end{array}$} & Seftriakson & $6(\% 31,6)$ & $0(\% 0)$ & $6(\% 23,1)$ & 2,874 & 0,146 \\
\hline & Oseltamivir & $3(\% 15,8)$ & $0(\% 0)$ & $3(\% 11,5)$ & 1,249 & 0,540 \\
\hline & Vankomisin & $2(\% 10,5)$ & $0(\% 0)$ & $2(\% 7,7)$ & 0,798 & 1,000 \\
\hline & Klaritromisin & $6(\% 31,6)$ & $4(\% 57,1)$ & $10(\% 38,5)$ & 1,412 & 0,369 \\
\hline & Sefotaksim & $4(\% 21,1)$ & $0(\% 0)$ & $4(\% 15,4)$ & 1,742 & 0,546 \\
\hline & SulbaktamAmpisilin & $12(\% 63,2)$ & $6(\% 85,7)$ & $18(\% 69,2)$ & 1,222 & 0,375 \\
\hline & Ampisilin & $3(\% 15,8)$ & $0(\% 0)$ & $3(\% 11,5)$ & 1,249 & 0,540 \\
\hline & $\begin{array}{l}\text { Piperasilin- } \\
\text { tazobaktam }\end{array}$ & $1(\% 5,3)$ & $0(\% 0)$ & $1(\% 3,8)$ & 0,383 & 1,000 \\
\hline & Klindamisin & $1(\% 5,3)$ & $0(\% 0)$ & $1(\% 3,8)$ & 0,383 & 1,000 \\
\hline & Meropenem & $1(\% 5,3)$ & $0(\% 0)$ & $1(\% 3,8)$ & 0,383 & 1,000 \\
\hline \multirow{2}{*}{ Vücut sıcaklığg } & $<38^{\circ} \mathrm{C}$ & $8(\% 42,1)$ & $5(\% 71,4)$ & $13(\% 50)$ & \multirow{2}{*}{1,759} & \multirow{2}{*}{0,378} \\
\hline & $\geq 38{ }^{\circ} \mathrm{C}$ & $11(\% 57,9)$ & $2(\% 28,6)$ & $13(\% 50)$ & & \\
\hline \multirow{2}{*}{ Komorbidite } & Var & $6(\% 31,6)$ & $1(\% 14,3)$ & $7(\% 26,9)$ & \multirow{2}{*}{0,778} & \multirow{2}{*}{0,629} \\
\hline & Yok & $13(\% 68,4)$ & $6(\% 85,7)$ & $19(\% 73,1)$ & & \\
\hline
\end{tabular}

$\chi^{2}$ : Fisher Tam Ki-Kare Testi 
Tablo 2. Tüm olguların tedavi öncesi ve tedavi sırasındaki yaşamsal bulgularının değerlendirilmesi.

\begin{tabular}{lccc}
\hline & Dakikadaki solunum & Dakikadaki kalp atım & Oksijen Satürasyonu \\
Ölçüm Zamanı & sayısı & sayısı & $(\%)$ \\
& Ort \pm SS (Medyan) & Ort \pm SS (Medyan) & Ort \pm SS (Medyan) \\
\cline { 2 - 4 } & $72,08 \pm 9,98(70)$ & $162,73 \pm 11,19(161)$ & $88,85 \pm 1,49(89)$ \\
\hline Tedavi Öncesi & $67,23 \pm 8,59(66)$ & $157,15 \pm 10,33(157,5)$ & $91,15 \pm 1,35(91)$ \\
Tedavi Sonrası 1.saat & $64,00 \pm 8,78(63)$ & $152,23 \pm 10,12(152)$ & $92,54 \pm 1,56(93)$ \\
Tedavi Sonrası8.saat & $59,69 \pm 8,44(60)$ & $147,96 \pm 9,62(148)$ & $93,23 \pm 1,56(93,5)$ \\
Tedavi Sonrası12.saat & $56,12 \pm 8,60(57)$ & $142,69 \pm 10,21(142)$ & $94,54 \pm 1,42(95)$ \\
Tedavi Sonrası 24.saat & $51,73 \pm 8,72(50)$ & $137,31 \pm 11,08(137)$ & $95,65 \pm 1,6(95,5)$ \\
\hline$\chi^{2}$ & $\mathbf{1 1 7 , 2 2 2}$ & $\mathbf{1 0 7 , 2 3 6}$ & $\mathbf{1 1 8 , 8 2 8}$ \\
\hline P & $\mathbf{0 , 0 0 1 * *}$ & $\mathbf{0 , 0 0 1} * *$ & $\mathbf{0 , 0 0 1} * *$ \\
\hline$\chi^{2}:$ Fisaat & & & \\
\hline
\end{tabular}

$\chi^{2}$ : Friedman Testi $* * \mathrm{p}<0,01$ 


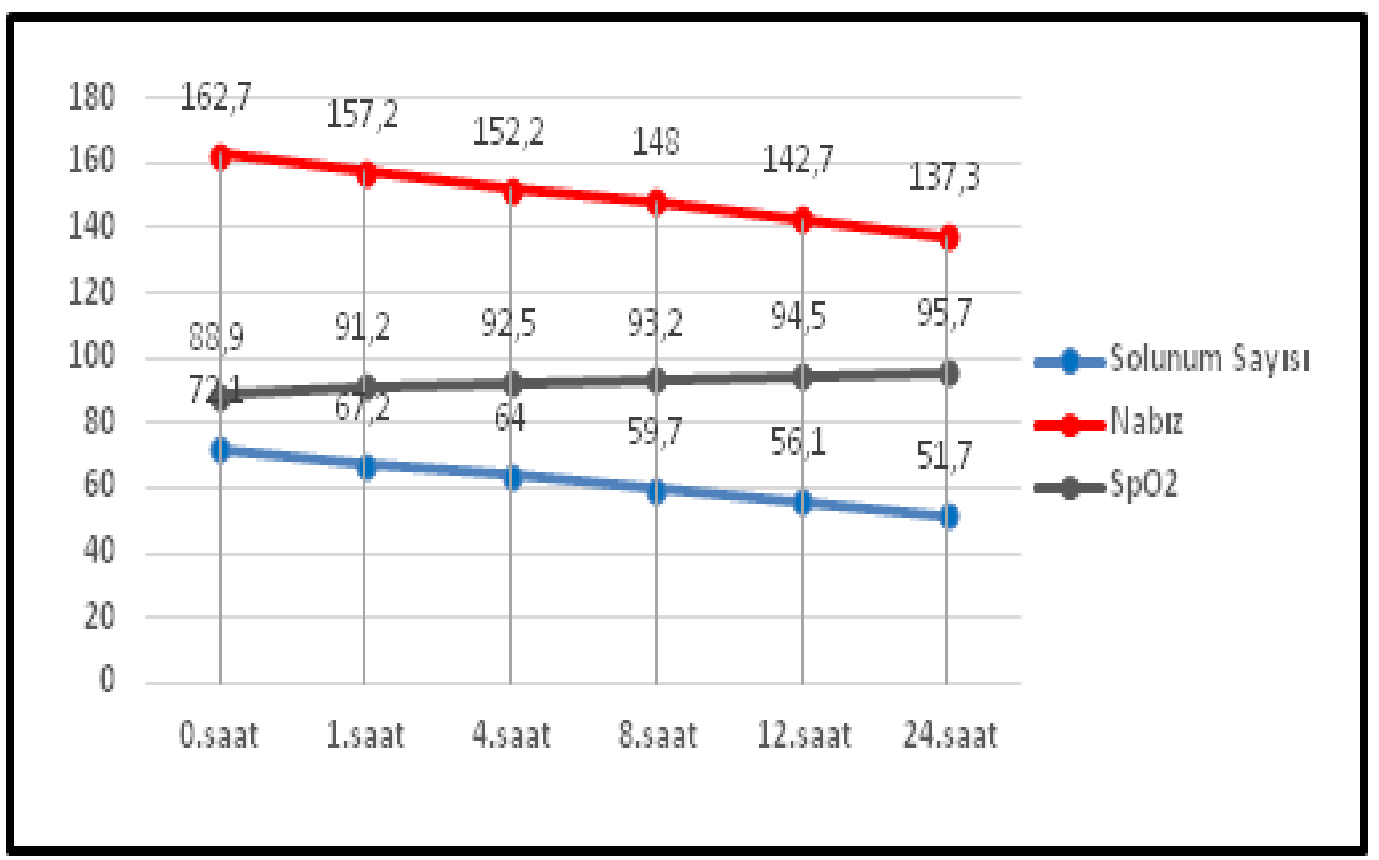

Şekil 1. Tüm Olguların Yaşamsal Bulgu Değişimleri. 
Tablo 3. Olguların tanı gruplarına göretedavi öncesi ve tedavi sırasındaki yaşamsal bulgularının değerlendirilmesi.

\begin{tabular}{|c|c|c|c|c|c|}
\hline Yasamsal & & Pnömoni (n=19) & Bronşiyolit (n=7) & & \\
\hline Bulgular & & & & & \\
\hline & & Ort \pm SS (Medyan) & Ort \pm SS (Medyan) & $\mathbf{Z}$ & $\mathbf{P}$ \\
\hline & Tedavi öncesi & $72,00 \pm 10,48(74)$ & $72,29 \pm 9,27(70)$ & $-0,319$ & 0,750 \\
\hline & Tedavi sonrası 1.saat & $67,21 \pm 8,93(66)$ & $67,29 \pm 8,26(66)$ & $-0,290$ & 0,772 \\
\hline & Tedavi sonrası 4.saat & $63,95 \pm 9,09(62)$ & $64,14 \pm 8,57(64)$ & $-0,116$ & 0,908 \\
\hline$\sum_{\bar{a}}^{\bar{n}}$ & Tedavi sonrası 8.saat & $59,32 \pm 8,60(60)$ & $60,71 \pm 8,58(60)$ & $-0,436$ & 0,663 \\
\hline$\Xi$ & Tedavi sonrası 12.saat & $55,79 \pm 8,99(54)$ & $57,00 \pm 8,06(58)$ & $-0,349$ & 0,727 \\
\hline है & Tedavi sonrası 24.saat & $51,84 \pm 9,31(50)$ & $51,43 \pm 7,55(52)$ & $-0,145$ & 0,884 \\
\hline 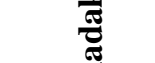 & $\chi^{2}$ & 82,515 & 35,000 & & \\
\hline 气ี & $\mathbf{P}$ & $0,001 * *$ & $0,001 * *$ & & \\
\hline & Tedavi öncesi & $160,89 \pm 12,28(160)$ & $167,71 \pm 5,47(168)$ & $-1,566$ & 0,117 \\
\hline & Tedavi sonrası 1.saat & $155,63 \pm 11,26(156)$ & $161,29 \pm 6,07(160)$ & $-1,419$ & 0,156 \\
\hline & Tedavi sonrası 4.saat & $150,42 \pm 10,65(150)$ & $157,14 \pm 6,94(157)$ & $-1,536$ & 0,125 \\
\hline 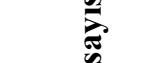 & Tedavi sonrası 8.saat & $146,58 \pm 10,29(146)$ & $151,71 \pm 6,78(150)$ & $-1,274$ & 0,203 \\
\hline 亚 & Tedavi sonrası 12.saat & $141,00 \pm 10,65(140)$ & $147,29 \pm 7,76(146)$ & $-1,248$ & 0,212 \\
\hline $\bar{\Xi}$ & Tedavi sonrası 24.saat & $136,16 \pm 12,08(136)$ & $140,43 \pm 7,61(140)$ & $-1,047$ & 0,295 \\
\hline$\frac{\bar{\sigma}}{\sigma}$ & $\chi^{2}$ & 72,798 & 35,000 & & \\
\hline$\frac{\pi}{\tilde{a}}$ & $\mathbf{P}$ & $\mathbf{0 , 0 0 1 * *}$ & $0,001 * *$ & & \\
\hline & Tedavi öncesi & $88,74 \pm 1,56(89)$ & $89,14 \pm 1,35(89)$ & $-0,533$ & 0,594 \\
\hline & Tedavi sonrası 1.saat & $91,16 \pm 1,42(91)$ & $91,14 \pm 1,21(92)$ & $-0,242$ & 0,809 \\
\hline & Tedavi sonrası 4.saat & $92,68 \pm 1,57(93)$ & $92,14 \pm 1,57(93)$ & $-0,519$ & 0,603 \\
\hline$\frac{\partial}{2}$ & Tedavi sonrası 8.saat & $93,16 \pm 1,38(93)$ & $93,43 \pm 2,07(94)$ & $-0,709$ & 0,478 \\
\hline $\bar{\Xi}$ & Tedavi sonrası 12.saat & $94,53 \pm 1,26(94)$ & $94,57 \pm 1,90(95)$ & $-0,474$ & 0,635 \\
\hline 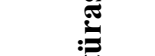 & Tedavi sonrası 24.saat & $95,63 \pm 1,50(95)$ & $95,71 \pm 1,98(96)$ & $-0,265$ & 0,791 \\
\hline$\ddot{\omega}$ & $\chi^{2}$ & 85,023 & 34,331 & & \\
\hline$\frac{\pi}{0}$ & $\mathbf{P}$ & $0,001 * *$ & $0,001 * *$ & & \\
\hline
\end{tabular}

